\title{
Pedagogia do Teatro e a Encenação em Movimento do Grupo Cena Aberta: caminhos de formação do artista-docente
}

\section{Resumo}

Visando compreender as possibilidades estéticas e educativas que se esboçam na teatralidade contemporânea, o presente trabalho se pauta na discussão plural que engloba os conceitos e as propostas teóricas sobre arte e educação, na tentativa de identificar as maneiras pelas quais se cria e aprecia o teatro na contemporaneidade, considerando as repercussões deste processo no âmbito da Pedagogia da cena. A perspectiva conceitual configura o processo de criação teatral como substrato das questões estéticas, éticas, políticas e educativas que sustentam a prática artística, considerando a experiência estética e o domínio da linguagem cênica. O trabalho de campo tem como principal recorte analítico os processos de criação do grupo de teatro Cena Aberta, do Maranhão, com enfoque nos modos educativos, estabelecidos pelo grupo, de se pensar a cena e a formação do artista.

Palavras-chave: Pedagogia do teatro; Experiência Estética; Contemporaneidade. Educação; Prática Artística

\section{Résumé}

Afin de comprendre les possibilités esthétiques et éducatives qui se profilent dans la théâtralité contemporaine, ce travail est guidé pour la discussion qui inclut les concepts pluriels et propositions théoriques sur l'art et l'éducation dans une tentative d'identifier les moyens par lesquels vous créez et profitez du théâtre dans de nos jours, compte tenu des implications de ce processus au sein de la pédagogie de la scène. Le point de vue conceptuel configure le processus de création de théâtre en tant que substrat des esthétiques, éthiques, politiques et éducatif qui soutiennent la pratique artistique, alors que de l'expérience esthétique et le domaine de la langue pittoresque. Le travail de terrain a comme ses principaux approche analytique le processus de la création de groupe de théâtre Cena Aberta, dans le Maranhão, se concentrer sur les modes d'éducation, établi par le groupe, penser la scène et la formation de l'artiste.

Mots-clés: pédagogie du théâtre; l'expérience esthétique, contemporain; éducation; pratique artistique. 
A partir das viradas conceituais e culturais ocorridas no século $\mathrm{XX}$, emergiram processos de criação que apontam para uma estética de cunho pautado na experiência e na educação estética gerada pela própria cena, assim, com o surgimento da encenação e da ideia de teatralidade, os conteúdos do teatro tornaram-se os próprios elementos que o compõem. Logo, interpretação, iluminação, caracterização, dramaturgia, cenografia, espaço cênico, recepção e crítica teatral passaram a ser o substrato da pesquisa estética do teatro.

O discurso político do teatro se inscreve na relação forma e conteúdo dos processos de criação e se relaciona diretamente com o caráter crítico-idealista que compõe a obra. Em geral, é no teatro experimental, aquele que vai na contramão da cultura massiva, que tanto se lança um olhar crítico em relação aos processos societários, quanto se preocupa na realização de ações culturais, que levem a uma mediação estética. Por outro lado, no que tange ao processo ético do artista, discute-se sobre sua tomada de consciência em relação ao exercício crítico do seu ofício, pois sabe-se que, enquanto profissional da arte, ele também é um formador de opiniões e gerador de conhecimentos.

A busca por uma nova postura do artista em relação ao mundo e ao exercício de seu trabalho foi fundamental para a reflexão dos aspectos éticos que são inerentes ao processo de criação, pois, se o teatro tornou-se um lugar mecanismo de discussão política, os agentes deste processo passaram também a ter uma consciência crítica sobre a função do seu trabalho na sociedade.

É neste contexto que o Grupo de Pesquisa Teatral Cena Aberta propõe ao seu elenco um posicionamento para além da atuação, relacionado a um trabalho em movimento durante o processo criador, onde de modo educativo e colaborativo a iluminação, caracterização, cenografia, dramaturgia e outros elementos da encenação, são pensados de modo colaborativo ao logo do processo. Trata-se de um procedimento que visa democratizar os saberes da cena, tendo em vista o processo estético, político e ético da obra de arte e o processo formativo do artista.

Criado no final dos anos 90, o Grupo Cena Aberta, coordenado pelo professor e encenador Luiz Roberto de Souza (Pazzini), nasceu da efervescência dos processos teatrais experimentais na Universidade Federal do Maranhão e foi criado para dar suporte ao processo de formação dos estudantes de graduação, futuros professores de teatro, tendo como metodologia de trabalho a investigação do teatro experimental, a discussão política da obra e a ética do artista de teatro. Para o grupo, a criação de uma encenação deve ser cíclica, construída processualmente por meio de experimentações que levem a algum lugar político, 
pois o lugar do conhecimento no teatro experimental seria a própria investigação contínua sobre a cena, na qual teoria e prática devem ser pensadas de modo simbiótico.

A proposta metodológica do grupo, encenação em movimento, aponta para uma perspectiva experimental de pesquisa em teatro, na tentativa de investigar as possibilidades de construção do saber na cena contemporânea, priorizando a formação política e estética do artista na praxe do teatro colaborativo. O termo movimento remete a duas importantes questões - ação e criação - com ramificações no caráter estético e ético da obra. A ação relaciona-se à atitude do artista junto à obra de arte e a sua pesquisa individual, pois sem um mínimo de autonomia e perspicácia não se consegue colocar em prática os conceitos trabalhados no grupo, como, por exemplo, o ator-compositor e o artista-docente, que são caros para a proposta metodológica desenvolvida pelo coletivo.

A criação dos espetáculos relaciona-se com as ações colaborativas desenvolvidas em grupo. Assim, se a ação se refere a uma atitude investigativa perante a obra, a criação é o apuramento estético desta atitude, de modo que o agir gera um movimento ético e o criar um movimento estético no grupo. A criação, sendo a face estética colaborativa de ações individuais e coletivas, ocorre permanentemente, pois se trata do mesmo de um caminho pedagógico e educativo.

\section{Referências}

SANTANA, Arão Nogueira Paranaguá de. Teatro e formação de professores. São Luís: EDUFMA, 2000.

. A presença do teatro na educação ludovicense. In SANTANA, A. N. P de (Coord.);

SOUZA, L. R.; RIBEIRO, T. C. Visões da Ilha: Apontamentos sobre Teatro e Educação. São Luís: EDUFMA, 2003. 